Proc. Estonian Acad. Sci. Eng., 2006, 12, 4, 455-463

\title{
$\alpha$-sialon ceramics fabricated from nanopowders by sintering and hot pressing
}

\author{
Ilmars Zalite $^{\mathrm{a}}$, Natalja Zhilinska ${ }^{\mathrm{a}}$, Aija Krumina ${ }^{\mathrm{a}}$ and Gottfried Kladler ${ }^{\mathrm{b}}$ \\ a Institute of Inorganic Chemistry, Riga Technical University, 34 Miera Str., Salaspils, LV-2169, \\ Latvia; ilmars@nki.lv \\ b ARC Seibersdorf Research GmbH, A-2444, Seibersdorf, Austria
}

Received 2 June 2006, in revised form 25 September 2006

\begin{abstract}
Investigation of the fabrication of $\alpha$-sialon ceramics from nanopowders by the method of ordinary sintering $\left(1200-1650^{\circ} \mathrm{C}\right)$ and hot pressing $\left(1800\right.$ and $\left.1910^{\circ} \mathrm{C}\right)$ was carried out. Samples of sialons were made by using $\mathrm{Si}_{3} \mathrm{~N}_{4}-\mathrm{AlN}-\mathrm{Al}_{2} \mathrm{O}_{3}$ and $\mathrm{Si}_{3} \mathrm{~N}_{4}-\mathrm{AlN}-\mathrm{Al}_{2} \mathrm{O}_{3}-\mathrm{Y}_{2} \mathrm{O}_{3}$ nanopowder composites, fabricated by the method of plasmachemical synthesis. Samples from nanopowders attain the density of $95-98 \%$ already at $1550-1600^{\circ} \mathrm{C}$, while industrial powders at the temperature of 1600 $1650{ }^{\circ} \mathrm{C}$ reach the density of only $60-85 \%$. The highest hardness of materials from nanopowders was attained after sintering at $1600-1650{ }^{\circ} \mathrm{C}$ and is $H V_{5}=21-23 \mathrm{GPa}$ depending on the composition. These results correspond well with properties of nanopowders obtained by hot pressing at $1800-1910^{\circ} \mathrm{C}$ (at $1910^{\circ} \mathrm{C}$ the hardness is $H V_{1}=20-21 \mathrm{GPa}$, bending strength $\sigma_{3 \mathrm{p}}=520-670 \mathrm{MPa}$ and fracture toughness $K_{1 \mathrm{c}}=4.0-7.0 \mathrm{MPa} \cdot \mathrm{m}^{1 / 2}$, depending on the composition).
\end{abstract}

Key words: sialon ceramics, nanopowders, sintering, hot pressing.

\section{INTRODUCTION}

Special interest on sialon ceramics is related to their increased mechanical properties (hardness, fracture toughness and strength). Due to good corrosion resistance and mechanical characteristics, silicon nitride based ceramic materials, including sialons, are promising candidates for structural materials $\left[{ }^{1}\right]$ for application at increased temperatures up to $1200^{\circ} \mathrm{C}$.

A lot of investigations $\left[{ }^{2-4}\right]$ have been carried out during last years on the preparation of sialon ceramics, especially on the effect of microstructure of materials on their properties.

Sialon ceramics are being prepared from powders and therefore properties of ceramic materials depend to a large extent on the quality of the starting powders. 
The powder determines the processing, the sintering behaviour and the subsequent formation of the microstructure, which strongly influences many properties of dense materials $\left.{ }^{5}\right]$.

According to $\left.{ }^{6}\right]$, there are two approaches to improve mechanical properties of ceramics. One is the control of the microstructure and another is the fabrication of the composite. The microstructure of the material can be significantly changed by using nanosized compounds and their composites for the preparation of materials. The distinctive properties of nanophase materials are lowtemperature plasticity, high diffusion coefficient and high solubility. Investigations of the preparation of $\mathrm{Si}_{3} \mathrm{~N}_{4}-\mathrm{Al}_{2} \mathrm{O}_{3}-\mathrm{Y}_{2} \mathrm{O}_{3}$ and sialon ceramics from nanopowders $\left[{ }^{7-9}\right]$ show that the application of nanopowders allows to decrease sintering temperature of powders and obtain ceramics with finer structure and changed properties.

The aim of this work was to investigate the compacting process of $\alpha$-sialon nanopowders of several composition in the system $\mathrm{Si}_{3} \mathrm{~N}_{4}-\mathrm{AlN}-\mathrm{Al}_{2} \mathrm{O}_{3}-\mathrm{Y}_{2} \mathrm{O}_{3}$ by sintering and hot pressing method as well as comparison of the ceramics with materials, obtained in similar conditions from industrial powders.

\section{EXPERIMENTAL}

Investigations were made on the preparation of $\alpha$-sialon ceramic materials of different compositions from nanopowder composites. Three series of $\alpha$-sialon were investigated with formulas $\mathrm{Y}_{0.57} \mathrm{Si}_{9.23} \mathrm{Al}_{2.77} \mathrm{O}_{1.05} \mathrm{~N}_{14.95}, \quad \mathrm{Y}_{0.45} \mathrm{Si}_{9.69} \mathrm{Al}_{2.31} \mathrm{O}_{0.95} \mathrm{~N}_{15.05}$ and $\mathrm{Y}_{0.48} \mathrm{Si}_{9.39} \mathrm{Al}_{2.61} \mathrm{O}_{1.17} \mathrm{~N}_{14.83}$. Nanopowders $\left(\mathrm{Si}_{3} \mathrm{~N}_{4}-\mathrm{AlN}-\mathrm{Al}_{2} \mathrm{O}_{3}\right.$ and $\mathrm{Si}_{3} \mathrm{~N}_{4}-\mathrm{AlN}$ $\mathrm{Al}_{2} \mathrm{O}_{3}-\mathrm{Y}_{2} \mathrm{O}_{3}$ ) (Table 1) were produced by the method of plasmachemical synthesis and have an average particle size of $30-50 \mathrm{~nm}\left[{ }^{10}\right]$. Micrographs of some nanopowders are given in Fig. 1.

The composition of the starting mixtures was, in general, restricted to the concentration plane $\mathrm{Si}_{12} \mathrm{~N}_{16}-\mathrm{Al}_{12} \mathrm{O}_{12} \mathrm{~N}_{4}-\mathrm{Y}_{4} \mathrm{Al}_{12} \mathrm{~N}_{16}$, so the final compositions would be monolithic $\alpha$-sialon, according to the phase diagram $\left[{ }^{11}\right]$. The specimen compositions used are plotted in Fig. 2 and given in Table 2.

Table 1. Chemical composition and size distribution of the starting powders

\begin{tabular}{l|c|c|c|c|c|c|c}
\hline \multirow{2}{*}{ Powder } & \multicolumn{5}{|c|}{ Chemical composition, wt\% } & $\begin{array}{c}\mathrm{SSA}^{*}, \\
\mathrm{~m}^{2} / \mathrm{g}\end{array}$ & $\begin{array}{c}d_{50}, \\
\mathrm{~nm}\end{array}$ \\
\cline { 2 - 6 } & $\mathrm{Si}_{3} \mathrm{~N}_{4}$ & $\mathrm{AlN}$ & $\mathrm{Al}_{2} \mathrm{O}_{3}$ & $\mathrm{Y}_{2} \mathrm{O}_{3}$ & $\mathrm{Si}_{\text {free }}$ & & \\
\hline $\mathrm{Si}_{3} \mathrm{~N}_{4}-\mathrm{AlN}_{-} \mathrm{Al}_{2} \mathrm{O}_{3}$ & 85.8 & 9.7 & 3.9 & - & 0.6 & 50 & 40 \\
$\mathrm{Si}_{3} \mathrm{~N}_{4}-\mathrm{AlN}_{-} \mathrm{Al}_{2} \mathrm{O}_{3}-\mathrm{Y}_{2} \mathrm{O}_{3}$ & 83.7 & 8.0 & 2.6 & 4.1 & 1.3 & 70 & 30
\end{tabular}

\footnotetext{
* Specific surface area.
} 

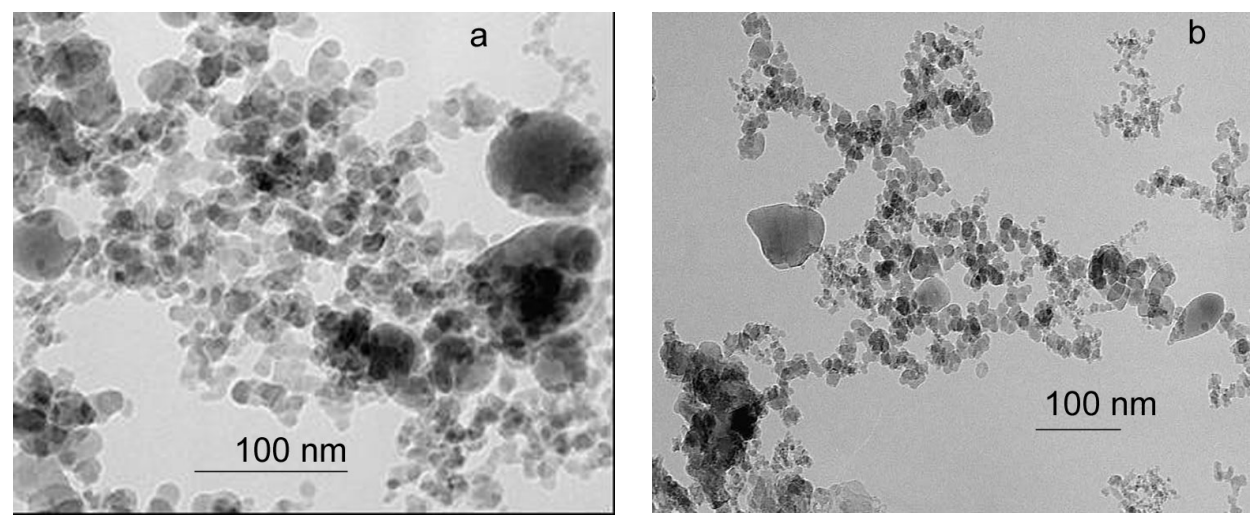

Fig. 1. Micrographs of $\mathrm{Si}_{3} \mathrm{~N}_{4}-\mathrm{Al}_{2} \mathrm{O}_{3}-\mathrm{AlN}$ (a) and $\mathrm{Si}_{3} \mathrm{~N}_{4}-\mathrm{AlN}^{-} \mathrm{Al}_{2} \mathrm{O}_{3}-\mathrm{Y}_{2} \mathrm{O}_{3}$ (b) nanopowders.

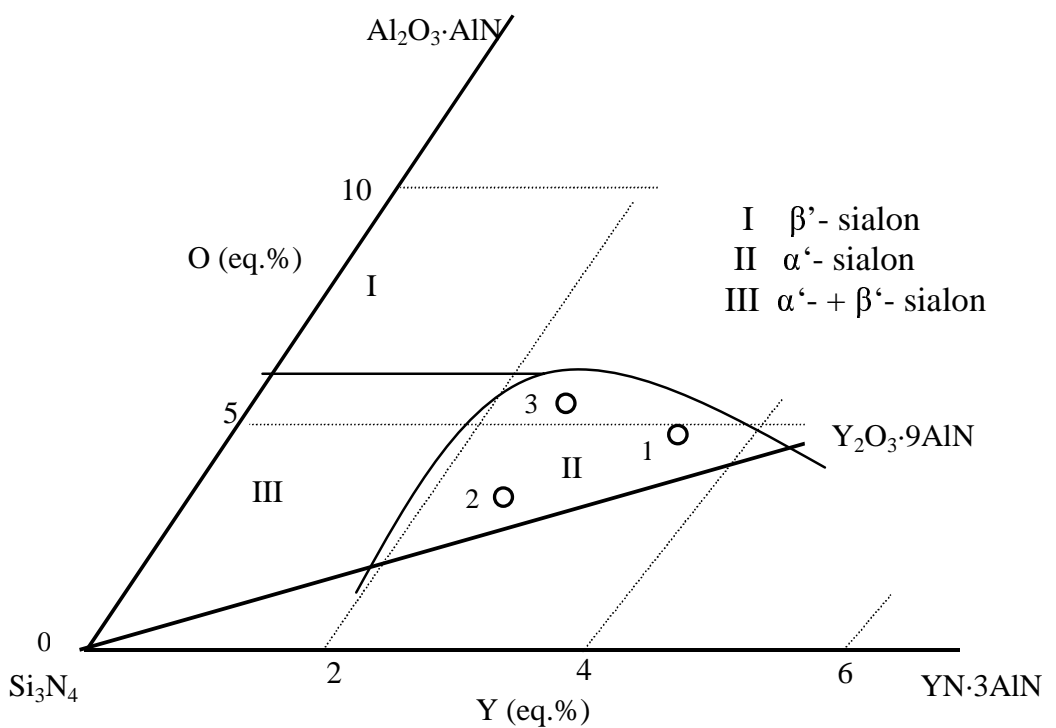

Fig. 2. Specimen composition spots in the phase diagram of the Y-Si-Al-O-N system.

Table 2. Composition of $\alpha$-sialon specimens, wt $\%$

\begin{tabular}{c|c|c|c|c|c|c}
\hline No. & $\mathrm{Si}_{3} \mathrm{~N}_{4}$ & $\mathrm{AlN}$ & $\mathrm{Al}_{2} \mathrm{O}_{3}$ & $\mathrm{Y}_{2} \mathrm{O}_{3}$ & $\mathrm{~m}^{*}$ & $\mathrm{n}^{*}$ \\
\hline 1 & 69.3 & 16.6 & 1.8 & 12.3 & 1.72 & 1.05 \\
2 & 74.0 & 15.7 & 2.2 & 8.0 & 1.36 & 0.95 \\
3 & 72.9 & 16.9 & 2.2 & 8.1 & 1.44 & 1.17
\end{tabular}

* " $\mathrm{m}$ " and " $\mathrm{n}$ " are independent composition parameters in the general formula $\mathrm{Y}_{\mathrm{m} / 3} \mathrm{Si}_{12-(\mathrm{m}+\mathrm{n})} \mathrm{Al}_{\mathrm{m}+\mathrm{n}} \mathrm{O}_{\mathrm{n}} \mathrm{N}_{16-\mathrm{n}}$. 
Table 3. Properties of $\alpha$-sialon ceramics prepared by hot pressing $\left(\mathrm{N}_{2}, 2\right.$ h)

\begin{tabular}{|c|c|c|c|c|c|c|}
\hline No. & $\begin{array}{c}\text { Sintering } \\
\text { temperature, } \\
{ }^{\circ} \mathrm{C}\end{array}$ & $\begin{array}{l}\text { Density, } \\
\mathrm{g} / \mathrm{cm}^{3}\end{array}$ & $\begin{array}{c}\text { Open } \\
\text { porosity, } \\
\%\end{array}$ & $\begin{array}{c}\text { Bending } \\
\text { strength, } \\
\mathrm{MPa}\end{array}$ & $\begin{array}{c}\text { Hardness } \\
H V_{1}, \\
\mathrm{GPa}\end{array}$ & $\begin{array}{c}\text { Fracture } \\
\text { toughness, } \\
\text { MPa.m }^{1 / 2}\end{array}$ \\
\hline \multirow[t]{2}{*}{$1 \mathrm{~A}$} & 1800 & 3.33 & 0.1 & $345 \pm 20$ & $21.9 \pm 0.5$ & - \\
\hline & 1910 & 3.31 & 0 & $520 \pm 15$ & $20.8 \pm 0.7$ & $5.5 \pm 0.3$ \\
\hline \multirow[t]{2}{*}{$2 \mathrm{~A}$} & 1800 & 3.26 & 0.2 & $535 \pm 25$ & $21.1 \pm 0.8$ & - \\
\hline & 1910 & 3.26 & 0 & $620 \pm 30$ & $20.2 \pm 0.5$ & $4.0 \pm 0.2$ \\
\hline \multirow[t]{2}{*}{$3 \mathrm{~A}$} & 1800 & 3.23 & 0.2 & $525 \pm 30$ & $20.4 \pm 2.5$ & - \\
\hline & 1910 & 3.28 & 0 & $690 \pm 40$ & $20.9 \pm 0.8$ & $7.0 \pm 0.3$ \\
\hline $3 B$ & 1910 & 3.30 & 0 & $700 \pm 70$ & $20.8 \pm 0.7$ & $7.2 \pm 0.3$ \\
\hline
\end{tabular}

Samples of ceramics, obtained from nanopowders, were made by using

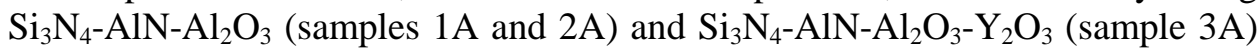
nanocomposites and small amount of AlN (H.C.Starck, grade B) and $\mathrm{Y}_{2} \mathrm{O}_{3}$ (H.C.Starck, grade C) powder additions for correcting of the composition (Table 3). Simultaneously, the sialon ceramics were obtained from commercial powders: $\alpha-\mathrm{Si}_{3} \mathrm{~N}_{4}$ (UBE, SN-10E), AlN (H.C.Starck, grade C), $\mathrm{Al}_{2} \mathrm{O}_{3}$ (Alcoa Chemie $\mathrm{GmbH}, \mathrm{A} 16 \mathrm{SG}$ ) and $\mathrm{Y}_{2} \mathrm{O}_{3}$ (Nanophase) in the same conditions for comparison (marked 1B, 2B and 3B).

All powders were mixed with $2 \mathrm{wt} \%$ of stearic acid, homogenized in hexane for $15 \mathrm{~h}$ in a rotating polyethylene bottle with silicon nitride balls and afterwards treated for $2 \mathrm{~h}$ in an ultrasonic bath. After the following drying at $80^{\circ} \mathrm{C}$ the powder was sieved through a $200 \mu \mathrm{m}$ mesh sieve. Green bodies with a diameter of $15 \mathrm{~mm}$ and a height of 7-8 $\mathrm{mm}$ were produced by die pressing with a pressure of $200 \mathrm{MPa}$. Ordinary sintering $\left(1200-1650^{\circ} \mathrm{C}\right)$ and hot pressing $(1800$ and $1910^{\circ} \mathrm{C}$ ) were used for compacting the materials. The temperature was raised $10 \% \mathrm{~min}$; isothermal holding time was $2 \mathrm{~h}$, sintering medium was nitrogen.

Chemical composition of the nanopowders $\left(\mathrm{N}, \mathrm{Si}_{\text {free }}, \mathrm{Y}, \mathrm{Al}\right)$ was determined by the chemical analysis. Phase composition of the sintered specimens was performed via X-ray diffractometry. The form and size of particles were determined by the transmitting electron microscope. The microstructure of the fracture surface was observed using scanning electron microscopy. Density of the sintered samples was determined by the Archimedes' method. Hardness (load 1 and $5 \mathrm{~kg}$ ) and fracture toughness (load $10 \mathrm{~kg}$ ) were measured by the Vickers indentation technique.

\section{RESULTS AND DISCUSSION}

Figure 3 shows the variation of the relative density during the sintering process. All materials showed nearly a constant relative density up to $1300^{\circ} \mathrm{C}$ for nano- and $1500^{\circ} \mathrm{C}$ for industrial powders. The densification of all samples obtained from nanopowders occurs at the temperature range of $1550-1600^{\circ} \mathrm{C}$ and 


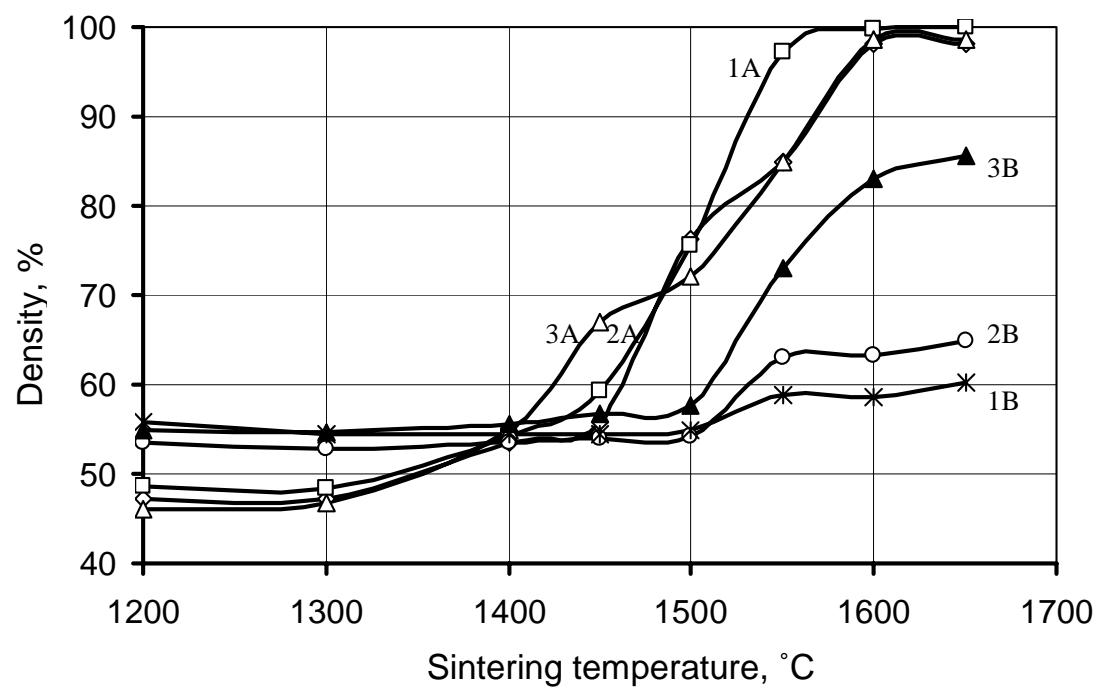

Fig. 3. Change of the relative density during sintering of the specimens.

at higher temperatures the increase of the density does not take place. Industrial powders almost do not sinter at the temperatures up to $1650^{\circ} \mathrm{C}-$ the density is $60-85 \%$ at the temperature of $1650^{\circ} \mathrm{C}$.

The phase formation by sintering of industrial and nanopowders is different. In the case of nanopowders, amorphous $\mathrm{Si}_{3} \mathrm{~N}_{4}$ first crystallizes into the $\alpha$ - and $\beta$-Si ${ }_{3} \mathrm{~N}_{4}$ until $1400^{\circ} \mathrm{C}$, but over $1400-1450^{\circ} \mathrm{C} \beta$-sialon begins to form; at over $1500^{\circ} \mathrm{C}$ also $\alpha$-sialon forms and its amount increases with the increase of the temperature. If at $1650{ }^{\circ} \mathrm{C}$ sample $1 \mathrm{~A}$ contains only $\alpha$-sialon, then sample $2 \mathrm{~A}$ contains also some $\beta$-sialon. The most characteristic is formation of $\beta$-sialon in sample 3A, where the formation of $\alpha$-sialon begins only at $1600^{\circ} \mathrm{C}$. With the increase of compacting temperature (for example, hot pressing at 1800 or $1910^{\circ} \mathrm{C}$ ) the proportion of $\alpha$-sialon phase increases. Incomplete phase transition in the samples of "A" series could occur due to increased oxygen content in nanopowders in comparison with the industrial powders.

In the samples of the "B" series, $\alpha$-sialon forms directly from $\alpha-\mathrm{Si}_{3} \mathrm{~N}_{4}$ already starting from $1450^{\circ} \mathrm{C}$ and at $1650^{\circ} \mathrm{C}$ the transition of $\alpha-\mathrm{Si}_{3} \mathrm{~N}_{4}$ to the $\alpha$-sialon has not been completely finished. Microstructure of the samples depends on their chemical composition. The grain size of samples from nanopowders at temperatures up to $1600^{\circ} \mathrm{C}$ changes insignificantly and is in the range of 200 $300 \mathrm{~nm}$. Also at the temperature of $1650^{\circ} \mathrm{C}$ the grain size of sintered samples does not change noticeably, except sample $2 \mathrm{~A}$, where the grain size increases a little bit (Fig. 4). The grain size increases in the samples of hot pressing: the average grain size is about $500 \mathrm{~nm}$ (Fig. 5). 

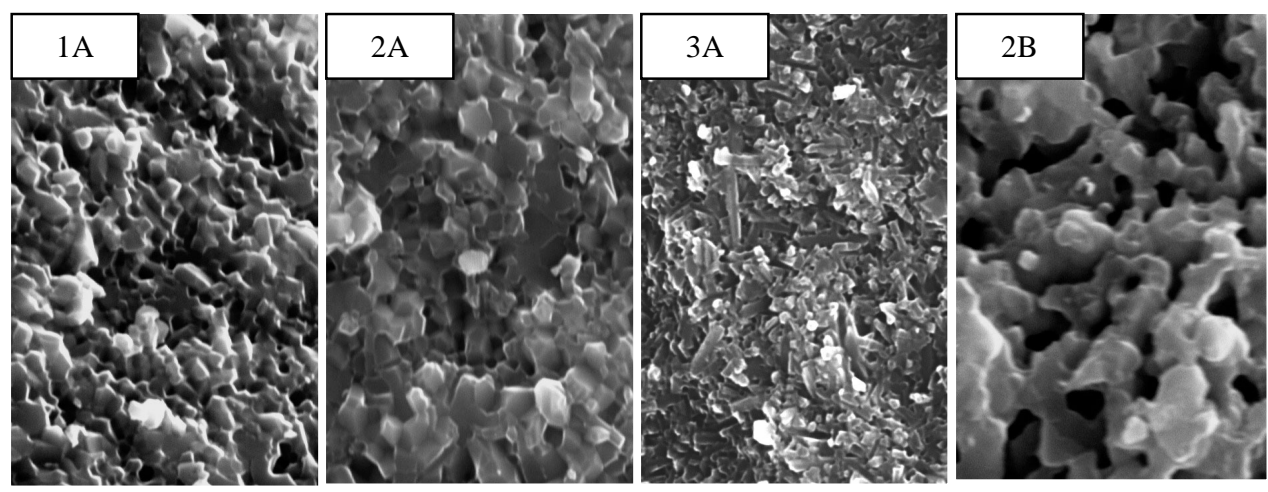

$1 \mu \mathrm{m}$

Fig. 4. Microstructure of the samples, sintered at $1650^{\circ} \mathrm{C}$.
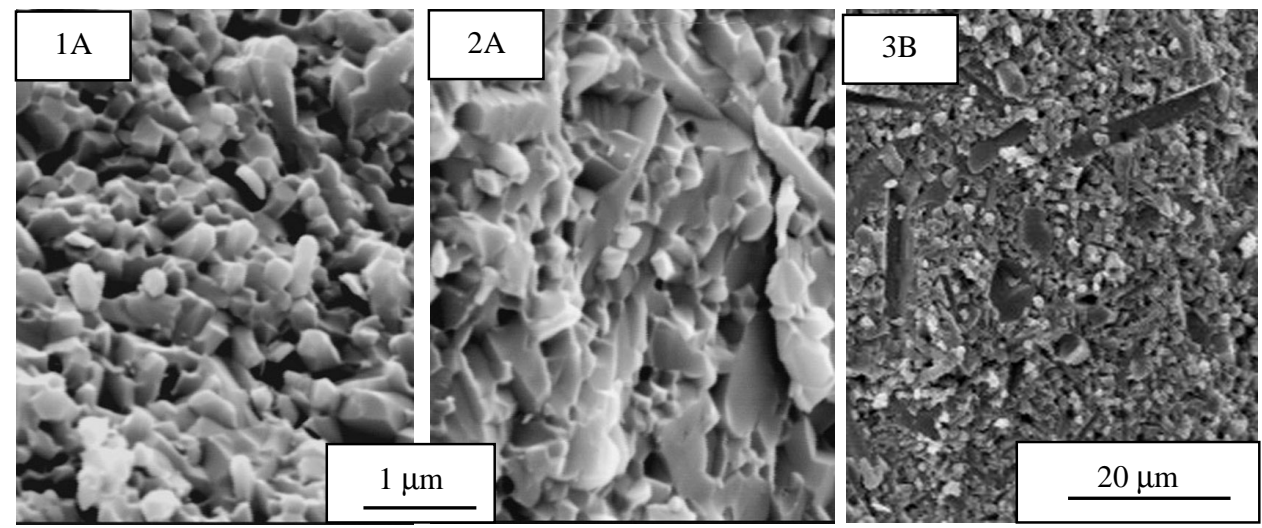

Fig. 5. Microstructure of the samples, hot pressed at $1800^{\circ} \mathrm{C}$.

Significant formation of needle-shaped crystals begins at the temperatures $1600-1650{ }^{\circ} \mathrm{C}$. It was observed especially in the hot pressed samples. Moreover, there are no needle-shaped crystals in the sample $1 \mathrm{~A}$, but in the sample $2 \mathrm{~A}$ the formation of such crystals is already characteristic, especially during hot pressing. In both cases the material consists only of the phase of $\alpha$-sialon. More characteristic formation of needle-shaped crystals was observed in the sample $3 \mathrm{~A}$, where the $\beta$-sialon phase has been preserved. The average size of needleshaped crystals is about $200 \mathrm{~nm}$ in crosscut and up to $2 \mu \mathrm{m}$ in length, but in samples, fabricated by the method of hot pressing, up to 3-4 $\mu \mathrm{m}$. The structure of samples, sintered at $1650^{\circ} \mathrm{C}$ from industrial powders, is porous and the grain size is about $0.5-1.0 \mu \mathrm{m}$; in the samples, prepared by hot pressing, grains are bigger 
and the length of needle-shaped crystals reaches $20 \mu \mathrm{m}$ (Fig. 5, 3B). Crystallite size (both for phases of $\alpha$ - and $\beta$-sialon) of samples, obtained from nanopowders at $1650^{\circ} \mathrm{C}$, is about $100 \mathrm{~nm}$, but in the samples of hot pressing the crystallite size is over $100 \mathrm{~nm}$.

Properties of the materials change proportionally to the density, phase composition, grain size and shape of the material. As it is shown in Fig. 6, hardness of obtained materials is directly related to their density. Samples sintered at $1550-1600{ }^{\circ} \mathrm{C}$ possess maximum hardness $\left(H V_{5}=20-23 \mathrm{GPa}\right)$, which a little bit decreases with rising of the sintering temperature (Table 3 ). The bending strength increases with the sintering temperature, probably due to grain size and shape: samples with isoaxial grains have higher hardness, but with needle-shaped crystals - higher bending strength. With the increase of the amount of needleshaped crystals also the fracture toughness increases. Materials sintered at $1650^{\circ} \mathrm{C}$ from industrial powders are not fully dense; therefore their hardness is small $\left(H V_{5}\right.$ varies from 2 to $\left.3 \mathrm{GPa}\right)$. Only the sample $3 \mathrm{~B}$ is more dense with higher hardness.

As it is seen in the densification process of hot pressing (Fig. 7), kinetics of densification of nanopowders and industrial powders are significantly different: in the case of nanopowders more significant is the starting stadium of compacting (at $1430-1550^{\circ} \mathrm{C}$ ), when the density grows due to the grain surface slipping.

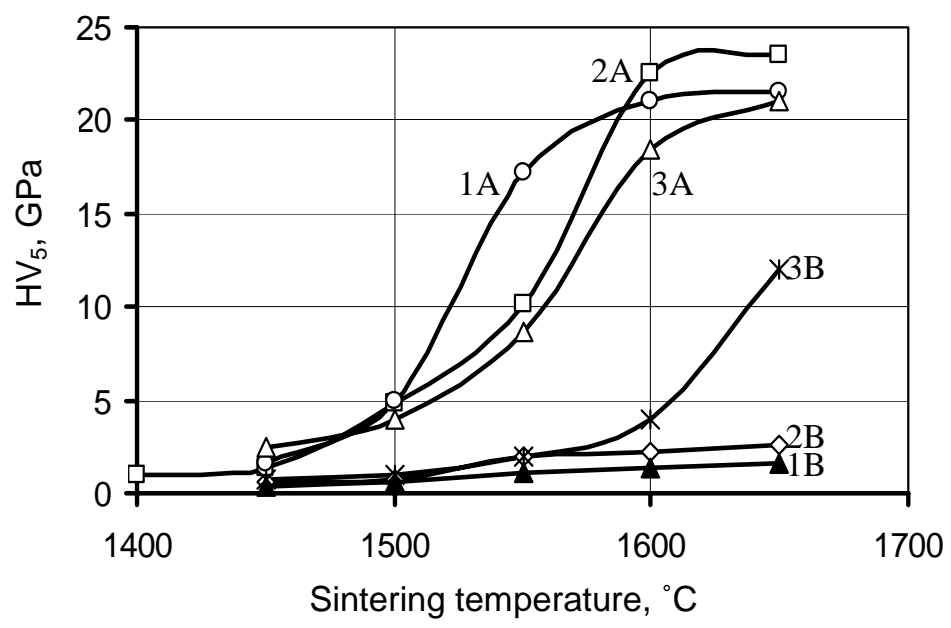

Fig. 6. Hardness of $\alpha$-sialon samples depending on the sintering temperature. 


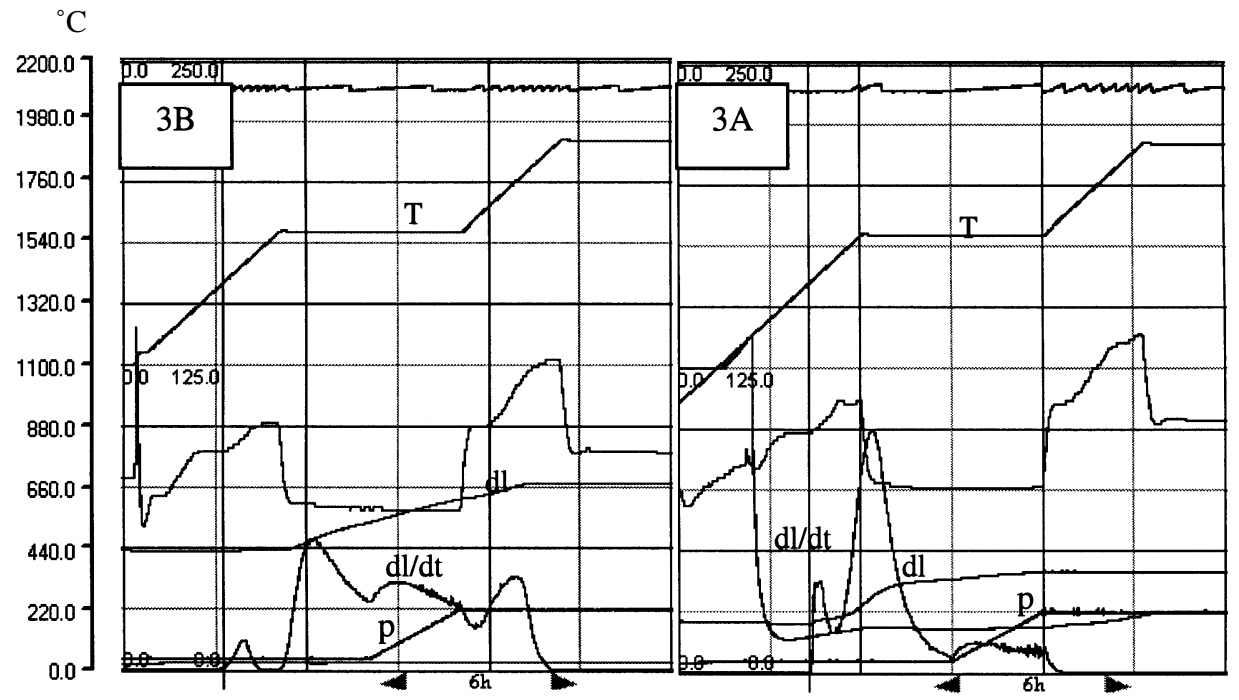

Fig. 7. Process of hot pressing of samples $3 \mathrm{~B}$ and $3 \mathrm{~A}$.

\section{CONCLUSIONS}

The densification behaviour of investigated powders in the sintering process depends on the composition and particle size of the starting powder. It is possible to obtain dense materials from a nanosized powder at a relatively low temperature $\left(1550-1600^{\circ} \mathrm{C}\right)$ with good mechanical properties at room temperature in comparison with a material made of a $\mu \mathrm{m}$-sized starting powder. The grain size of nanopowder materials is smaller $(200-300 \mathrm{~nm})$ than that of the commercial $\mathrm{Si}_{3} \mathrm{~N}_{4}$ powder.

If industrial powders are applied, the formation of $\alpha$-sialon takes place directly from $\alpha-\mathrm{Si}_{3} \mathrm{~N}_{4}$, but for nanopowders the $\beta$-sialon forms first and transforms to the $\alpha$-sialon at higher temperatures.

The hardness of obtained materials is directly related to their density and for samples from nanopowders at $1650^{\circ} \mathrm{C} H V_{5}$ was from 21 to $23 \mathrm{GPa}$. These results correspond well with properties of nanopowders obtained by hot pressing at $1800-1910^{\circ} \mathrm{C}$; for samples obtained at $1910^{\circ} \mathrm{C}$ the hardness $H V_{1}$ is from 20 to $21 \mathrm{GPa}$, bending strength $520-670 \mathrm{MPa}$ and fracture toughness 4.0 7.0 MPa.m ${ }^{1 / 2}$, depending on the composition.

\section{REFERENCES}

1. Gogotsi, Yu. G. Particulate silicon nitride-based composites. J. Mater. Sci., 2000, 29, 25412556.

2. Zhao, H., Wood, C. and Cheng, Y.-B. The effect of processing conditions on the microstructures of $\alpha$-SiAlON ceramics. Mater. Sci. Forum, 2000, 325-326, 213-218. 
3. Young, W. T., Falk, L. K. L., Lemercier, H. et al. The crystallisation of the yttrium-sialon glass: $\mathrm{Y}_{15.2} \mathrm{Si}_{14.7} \mathrm{Al}_{18.7} \mathrm{O}_{54.1} \mathrm{~N}_{7.4}$. J. Non-Crystall. Solids, 2000, 270, 6-19.

4. Kim, J., Rosenflanz, A. and Chen, I.-W. Microstructure control of in-situ-toughened $\alpha$-SiAlON ceramics. J. Am. Ceram. Soc., 2000, 83, 1819-1821.

5. Petzow, G. and Hermann, M. Silicon nitride ceramics. In Structure and Bonding. (Jansen, M., ed.). Springer, Berlin, 2002, 102, 71-72.

6. Hojo, J., Eto, K., Umezu, M. et al. Microstructure and mechanical properties of sintered bodies of fine powders in $\mathrm{Si}_{3} \mathrm{~N}_{4}$-TiN system. J. Ceram. Soc. Japan, 1998, No 1, 25-30.

7. Bulic, F., Zalite, I. and Zhilinska, N. Comparison of plasma-chemical synthesised - SiAlONnano-powder and conventional prepared SiAlON-powder. J. Eur. Ceram. Soc., 2004, 24, 3303-3306.

8. Zhilinska, N., Zalite, I., Krumina, A., Costin, W. and Mozdzen, G. Sintern der Materialien auf der Basis unterschiedlicher $\mathrm{Si}_{3} \mathrm{~N}_{4}$-Pulver. In Verbundwerkstoffe, 14. Symposium Verbundwerkstoffe und Werkstoffverbunde. Weinheim, 2003, 399-404.

9. Zalite, I., Zhilinska, N. and Krumina, A. Sintering of plasma-chemically synthesized SiAlON nanopowder. In Nanomaterials and Nanotechnologies (Zalite, I. and Krastins, J., eds.). Institute of Inorganic Chemistry, Riga Technical University, Riga, 2005, 98-103.

10. Zalite, I. Preparation of nanodisperse transition metals carbonitrides by the plasmachemical method. In Proc. European Congress and Exhibition on Powder Metallurgy. Nice, 2001, vol. 4, 188-193, CD.

11. Haviar, M. Influence of oxygen content on formation of yttrium $\alpha$-SiAlON ceramics. $J$. Am. Ceram. Soc., 1994, 77, 2425-2428.

\section{Nanopulbritest paagutamise ja kuumpressimise teel valmistatud $\alpha$-sialoonkeraamika}

\section{Ilmars Zalite, Natalja Zhilinska, Aija Krumina ja Gottfried Kladler}

On uuritud $\alpha$-sialoonkeraamika valmistamist nanopulbritest tavalise paagutamise (1200-1650 $\left.{ }^{\circ} \mathrm{C}\right)$ ja kuumpressimisega (1800 ja $\left.1910{ }^{\circ} \mathrm{C}\right)$. Sialoonist katsekehad on valmistatud plasmakeemilise sünteesi teel saadud $\mathrm{Si}_{3} \mathrm{~N}_{4}-\mathrm{AlN}-\mathrm{Al}_{2} \mathrm{O}_{3}$ ja $\mathrm{Si}_{3} \mathrm{~N}_{4}-\mathrm{AlN}-\mathrm{Al}_{2} \mathrm{O}_{3}-\mathrm{Y}_{2} \mathrm{O}_{3}$ nanopulbritest. Nendest valmistatud katsekehade tihedus 95-98\% saavutatakse juba $1550-1600{ }^{\circ} \mathrm{C}$ juures. Samas on tööstuslikest pulbritest $1600-1650{ }^{\circ} \mathrm{C}$ juures paagutatud katsekehade tihedus ainult $60-85 \%$. Suurim nanopulbritest valmistatud keraamika kõvadus $\left(H V_{5}=21-23 \mathrm{GPa}-\right.$ sõltuvalt koostisest) saadakse paagutamisel $1600-1650{ }^{\circ} \mathrm{C}$ juures. See on võrreldav kuumpressimisega temperatuuril $1800-1910{ }^{\circ} \mathrm{C}$ nanopulbritest valmistatud materjalide omadustega $\left(1910{ }^{\circ} \mathrm{C}\right.$ juures on kõvadus $H V_{1}=20-21 \mathrm{GPa}$ (sõltuvalt koostisest), paindetugevus 520-670 MPa ja purunemissitkus 4-7 MPa.m ${ }^{1 / 2}$ ). 